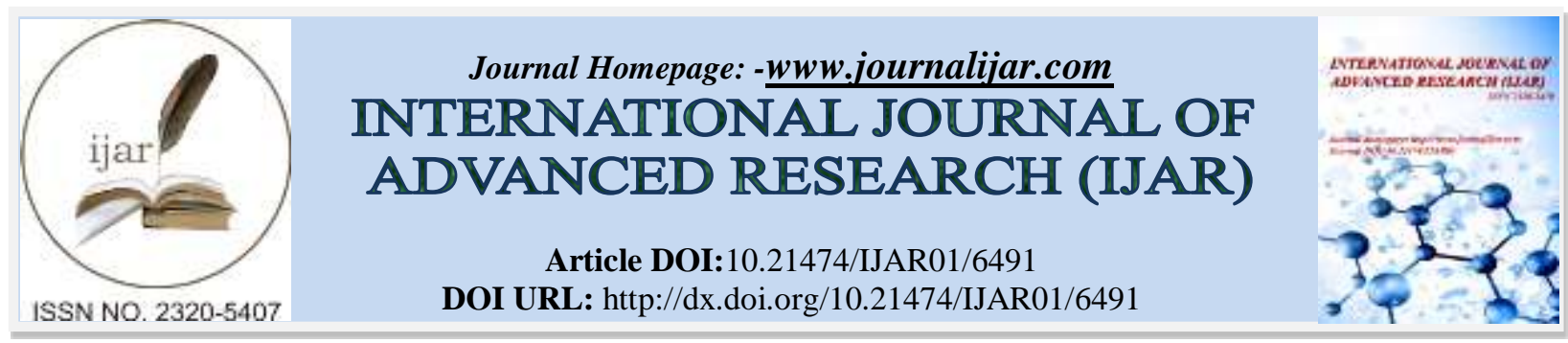

RESEARCH ARTICLE

\title{
THE IMPACT OF ONE BELT ONE ROAD INITIATIVE IN THE GARMENT SECTOR OF BANGLADESH.
}

Md. Emdadul Haque.

School of Management, Shanghai University, Shanghai, PR China - 200444.

\section{Manuscript Info}

Manuscript History

Received: 10 December 2017

Final Accepted: 12 January 2018

Published: February 2018

Keywords:-

One Belt One Road, Ready-made

Garments, Foreign direct investment, Bangladesh.

\section{Abstract}

As the second largest garments producer and exporter in the world market after china, Bangladesh's readymade garment industry is one of the most important sector among others sectors, which serves a big market all over the world. Ready-made garments (RMG) of Bangladesh is considered as the backbone of its economy and has a great prospect to become the leading garment producer and exporter in the world market near future. Considering the biggest initiative of OBOR by Chinese government also known as New Silk Road initiative, which will be connected with more than 60 countries and sixty percent of total population in the world, Bangladesh is considered as a very important land both geographically and economically and has already declared to join in this initiative. While in recent years, the production cost of apparel in china is increasing very high and the opportunity cost of garments production is much higher than Bangladesh. So many buyers and producers are looking for a new destination for their investments and apparel business. In this situation OBOR initiative could be a window of opportunity as foreign direct investment (FDI) especially for RMG industry of Bangladesh. This paper focuses to find out what will be the impact of OBOR initiative on Bangladesh's economy specifically on garment sectors, and how Bangladesh will be benefited from this project, beside what steps Bangladesh government should be taken to make it meaningful.

Copy Right, IJAR, 2018,. All rights reserved.

\section{Introduction:-}

Garment industry of Bangladesh is most emerging sector amongst others sectors. This sector is considered as the backbone of its economy which is the second largest garment producer and exporter in the world after China (Abdin MJ, 2014). This RMG sector contributes around $82 \%$ of Bangladesh's total exports earning and covered around $16 \%$ of total GDP (Ahmed, Raihan, \& Islam, 2013). Recently Bangladesh garment manufacturer and exporter association (BGMEA) has set a goal to export $\$ 50$ billion by 2021 and become a largest producer and exporter in the world near future. As we know China is the largest garment producer and exporter in the world and its exports around $\$ 175$ billion in 2016 beside it has a big market for readymade garments (Atm Adnan, 2016). Meanwhile, in 2013, Chinese government has taken One Belt One Road initiative (OBOR) which will be connected more than 60 countries in the world and more than $60 \%$ of total populations (Tian, 2016). Where Bangladesh is one of the important member of this initiative. In this research the author will try to find out how and why Bangladesh will be benefited from this OBOR initiative beside why it is important for Bangladesh specieficly for RMG sectors. 
As we know recently Bangladesh government, led by Prime Minister Sheikh Hasina, is firmly committed to materializing two important visions: a) becoming a middle-income country by 2021 and b) becoming a Developed Country by 2041(Divyansh, 2017). Beside Bangladesh Garment Manufacturer and Exporter Association (BGMEA) has fixed up a goal that export $\$ 50$ billion by 2021 and become largest garment producer and exporter in the world near future which currently second largest (Chowdhury et al., 2014). In this context OBOR initiative could play major role to achieve the goal. As China is the second largest economy in the world and it also the largest garment producer and exporter in the world. But the RMG production in china is not competitive any more in China because of increasing wages of labors and a sharp hike in overall production cost. Also the opportunities cost of garment production in China is much higher than Bangladesh where Bangladesh has the cheapest labor forces in the world beside Bangladesh government is offering some especial incentives for foreign investors and buyers who is looking for their new destination for their investment and source. In this context OBOR would be a windows of opportunities for Bangladeshi garment sectors. As because this project will be connected with more than 60 countries and $60 \%$ total population of the world and 40 percent of global GDP which is really important. Bangladesh is also very important country of this initiative and already it's declared to join this project. As we know China is the largest trading partner of Bangladesh. In 2017, Bangladesh has imported more than $\$ 16$ billion and exported only $\$ 1$ billion from China which is increasing very dramatically every year (Dr. Mahfuz Kabir, 2016). Also China is the most important development partner of Bangladesh and it's becoming stronger day by day. Recently Chinese precedent has visited Bangladesh and signed up several investment agreements between two countries also its declared more than 97\% Bangladeshi products duty free accessibility in Chinese market which is really great news for Bangladesh especially for garments industry. So it will be good for both for Bangladesh and Chinese economy. Both countries will be able to enjoy absolute advantages from this OBOR initiative and it will create win win situation for all.

\section{Objective of the study:-}

The main objective of this paper is to find out what will be impact of One Belt One Road Initiative (OBOR) on Garment Industry of Bangladesh. As Bangladesh garment industry is one of the most important sector amongst others sectors and it has a big market all over the world. Bangladesh is the second largest garments producer and exporter in the world market after china. RMG of Bangladesh is considered as the backbone of its economy. It has a very bright possibility to become number one garment producer and exporter in the world market near future. At the same time Chinese government has taken One Belt One Road initiative (OBOR) which is biggest initiative by a single country ever in the world. It also known as New Silk Road initiative in this context geographically and economically Bangladesh is considered as a very important country. In this situation Bangladesh could be a perfect destination for investors and producer. In this paper the author will try to find out what will be the impact of One Belt One Road (OBOR) initiative in Bangladesh's economy specifically on garment sectors and how Bangladesh will be benefited from this project beside what steps Bangladesh government should be taken to make its meaningful.

\section{Research Methodology:-}

The research will be the qualitative one. SWOT, analysis will be used for the explanation of the thesis. Also, here will be used some table and graphs about the economy of Bangladesh and China and One Belt One Road (OBOR), also RMG industry. Data will be collected from Different type of sources like, books, journals, and Internet sources are consulted for collection of necessary data and information, published materials such as the Bangladesh Economic Review, Different articles of Board of Investment (BOI) and Bangladesh Export Processing Zone (BEPZA), Daily Statement of Affairs of different Internet based publication, Bangladesh Garments Manufacturers and Export Association (BGMEA), International Monetary Fund (IMF), United Nation economic report on Bangladesh, World Bank(WB), Bangladesh Bureau of Statistics (BBS), Export Promotion Bureau(EPB), Bangladesh Bank (BB), World Trade Organization (WTO), business recorder database and other books on Foreign Investment, RMG industry in Bangladesh.

\section{Literature Review:-}

More than 2,000 years ago, China's imperial envoy Zhang Qian helped to establish the Silk Road, a network of trade routes that linked China to Central Asia and the Arab world. The name came from one of China's most important exports - silk. And the road itself influenced the development of the entire region for hundreds of years (The Indian Express, 2017). In 2013, China's president, Xi Jin ping, proposed establishing a modern equivalent, creating a network of railways, roads, pipelines, and utility grids that would link China and Central Asia, West Asia, and parts of South Asia. This initiative, One Belt and One Road (OBOR), comprises more than physical connections. It aims 
to create the world's largest platform for economic cooperation, including policy coordination, trade and financing collaboration, and social and cultural cooperation. Through open discussion, OBOR can create benefits for everyone. Bangladesh formally joined the Chinese OBOR initiative during President Xi Jinping's visit to the country in October 2016 (Dr. Mahfuz Kabir, 2016). Within the larger framework of OBOR, economic integration between Bangladesh and China is expected to grow. And China matters a lot to Bangladesh, considering the growing volume of trade along with other dimensions. Thus Bangladesh, as one of the participating countries will obviously benefit from this initiative.

Bangladesh has already received positive outcomes from its warm ties with China in recent times. With regard to the question of where does Bangladesh stand in the OBOR initiative, as Donald J. Lewis, Director of the Centre for International Economic Law, Trade \& Development wrote in China Daily (October 16, 2016) he land dimensions of the OBOR consist of several inter-connected corridors spanning the entire Eurasian continent. Bangladesh is centrally situated along the Bangladesh-China-India-Myanmar (BCIM) Economic Corridor (Nusrat, 2017). Bangladesh also occupies a strategic position along the 21st Century Maritime Silk Road with its bustling port of Chittagong as a major maritime hub through the Indian Ocean. As a part of the initiative, the BCIM (Bangladesh, China, India and Myanmar) corridor is now in its final stage. As both Bangladesh and China believe in regional cooperation and have common interest in the corridor, this offers additional impetus. While Chinese investors have interests in Bangladesh's garment industry due to the availability of cheap labor, the Chittagong and Mongla ports are also of great interests for China to develop connectivity for its Southern gateway. One Belt One Road' termed it as a win-win initiative for all., Minister for Planning of Bangladesh government AHM Mustafa Kamal said that China's OBOR initiative was not exactly new, it could be seen as an extension of the trade route set up 2000 years ago by the Han dynasty of China (The Daily Star, 2017). It was a purely trade route then, but now would be seen from the development perspective too.

This project could be cause of infrastructure connectivity, investment and trade facilities, and financial cooperation. China is now diversifying its investment into emerging markets and Bangladesh needs to take advantage of this economic opportunity. This initiative would be beneficial for all, harmful to none. As we know China's objective behind this initiative was to create a sphere of friendship and to expand development. Bangladesh should not go for policies that undercut the country's opportunities to benefit from the Chinese One Belt, One Road (OBOR) initiative. Understanding the overwhelming reach and potential of this project, it is evident that Bangladesh is poised to benefit enormously from the OBOR. Bangladesh could be a key player in the OBOR project, which may allow the country to pursue an infrastructure-led growth and so on. China wishes to build mega infrastructure projects within the Belt and Road areas to increase trade and service, offering substantial prospects for Bangladesh. This initiative meets Bangladesh's need for wider connectivity within the region. The OBOR could introduce a new era of win-win globalization where Bangladesh could be benefited by various ways specieficly garment industry.

\section{Garment Industry of Bangladesh:-}

Bangladesh garment industry is one of the most important sector amongst others sectors and it has a big market all over the world. Bangladesh is the second largest garments producer and exporter in the world market after china. RMG of Bangladesh is considered as the backbone of its economy. It has a great possibilities to become number one garment producer and exporter in the world market near future. In the early 1980s Bangladesh started receiving investment in the RMG sector (Hasan, 2013). Some Bangladeshis received free training from the Korean Company Daewoo. After these workers came back to Bangladesh, many of them broke ties with the factory they were working for and started their own. In 1980s, there were only 50 factories employing only a few thousand people. Currently, there are 4482 manufacturing units are producing RMG in Bangladesh (BGMEA, 2017). Majority of the garment firms in Bangladesh are locally own where about $1 \%$ of them operating in the export processing zones (EPZs) in the city of Dhaka and Chittagong but more than 63\% of EPZ firms have some foreign ownership from countries such as South Korea, China, Japan, UK, USA and Hong Kong (BBS, 2017).

Table:- Overview of Bangladesh RMG sector (2008 -2016)

\begin{tabular}{|l|l|l|l|l|}
\hline Year & Total RMG factory & $\begin{array}{l}\text { Total } \\
\text { workers(Mill\$) }\end{array}$ & Total export(Mill\$) & $\begin{array}{l}\text { \% of RMG'S to } \\
\text { total export }\end{array}$ \\
\hline 2008 & 4925 & 3.5 & 12496.72 & 75.83 \\
\hline 2009 & 5063 & 3.6 & 17914.49 & 79.33 \\
\hline 2010 & 5150 & 3.6 & 19089.73 & 77.12 \\
\hline 2011 & 5400 & 4 & 21515.73 & 78.15 \\
\hline
\end{tabular}




\begin{tabular}{|l|l|l|l|l|}
\hline 2012 & 5876 & 4 & 24491.88 & 78.55 \\
\hline 2013 & 4222 & 4 & 25491.4 & 79.61 \\
\hline 2014 & 4296 & 4 & 28094.16 & 81.13 \\
\hline 2015 & 4328 & 4 & 28130.44 & 81.68 \\
\hline 2016 & 4482 & 4 & 28149.84 & 82.01 \\
\hline
\end{tabular}

Source: Bangladesh Garment Manufacturer and Exporter Association (BGMEA2017)

Now the RMG sector contributes around 82 percent to the total export earnings. In 2017 it earned $\$ 29$ billion. This sector also contributes around 16 percent to the GDP, which was only around 3 percent in 1991. In 2016, the industry consisting of some 4482 factories employed directly more than 4 million workers of whom almost $80 \%$ were female. The garment sector is the largest employer of women in Bangladesh. The garment sector has provided employment opportunities to women from the rural areas that previously did not have any opportunity to be part of the formal workforce. This has given women the chance to be financially independent and have a voice in the family because now they contribute financially. This sector has a great contributes overall economy of Bangladesh. As a result, the country's per-capita income has shot up from US\$280 in 1990 to US\$1610 in 2016 (Bangladesh Bank, 2017).

\section{Bangladeshi RMG in the World Market:-}

Garments industry of Bangladesh is one of the well-known industry and it has a big market all over the world which is the second largest garments producer and exporter in the world market after china. Very recent years Bangladesh is becoming more and more popular destination for the apparel retailers and fashion brands worldwide as the country is consistently providing most competitive price maintaining acceptable quality standards. Existing merchants and brands are expanding their work order as well as new ones are coming to utilize the opportunities in order to make their products more competitive in the global apparel market. The daily star releases that renowned fashion brands like H\&M, Zara, GAP, Hugo Boss, Old Navy and Wal-Mart are intended to increase their sourcing from Bangladesh to a great extent. Many other retailers are also following the trend. Thus Bangladeshi RMG is very competitive in the world market. There are 4482 garment factory in Bangladesh, according BGMEA member list. They are producing and exporting their garment all over the world with good reputation. There is some popular company name. Ocean Fashion Ltd, Uttara Apparels Ltd, Mascot Apparel Ltd, Angel Fashion, Apex Spinning \& Knitting Mills Ltd, Fortune Garments Ltd, Federal garments Ltd, Hope Fashion Ltd, Scissors Apparels Pvt Ltd, Jessica Apparels Limited, Active Apparels (Pvt.) Ltd, and some others factory.

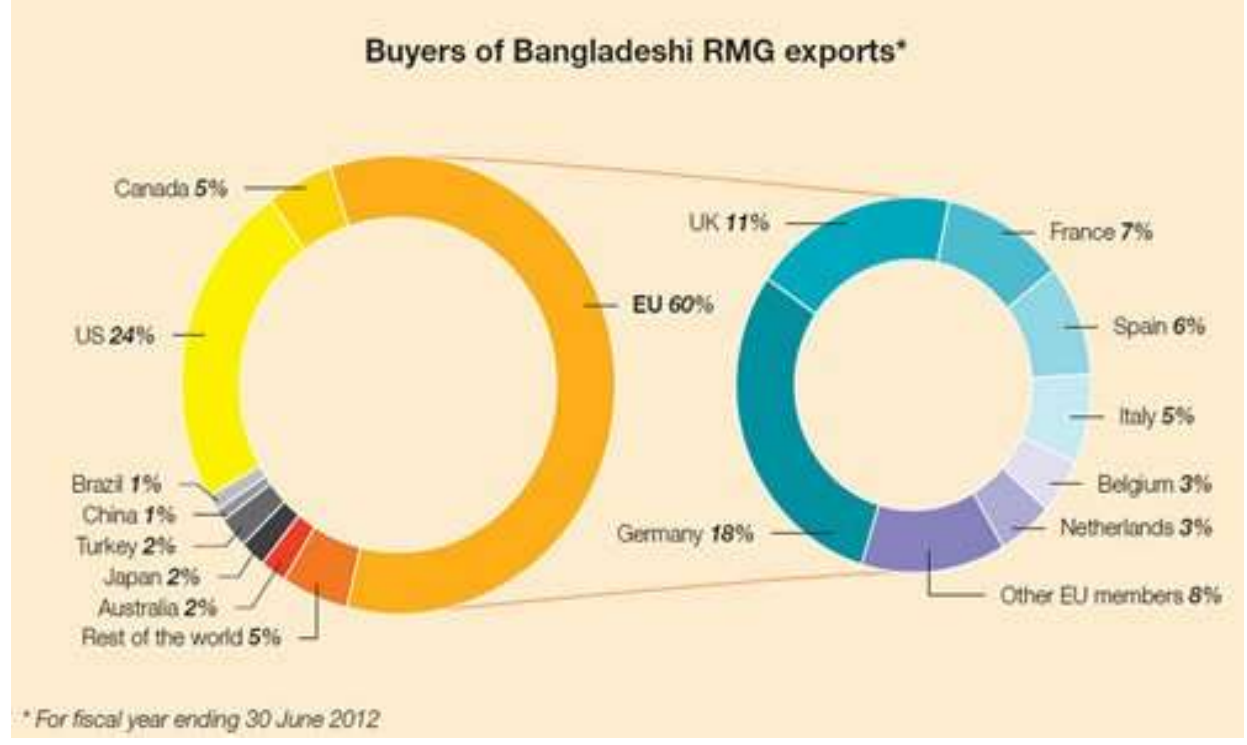

Source: Bangladesh Garment Manufacturers and Exporters Association (BGMEA)

Normally it's seen that, buyers of European countries, Canada, USA, UK, Japan, China, Australia, and India are the main buyers of Bangladeshi garments and Textile products. Among of them here I will mention some name of buyers which are very much important for Bangladeshi garments sector. There are some of buyers such. Adidas, H\&M. Decathlon, Wal-Mart, GAP, Levi's, Nike, Old Navy, US Polo, American Eagle, Academy, Peri Ellis, Zara, 
Sains Burry, C\&A, Hugo Boss, Esprit, Mango, Puma, European Eagle, M\&S, Tema, Terco, Decathlon, Carretow, NKD, Lindex. K-mart, Uniquelo, Hulson Bay, Black Berry and so on. Above mentioned diagram we can see that Bangladesh export $60 \%$ of its RMG to EU countries and $24 \%$ export to USA market beside others country in the world (Berg et al., 2011).

\section{Bangladeshi RMG in Chinese Market:-}

China is the second largest economy in the world after America with 1.40 billion populations. It has a biggest domestic market. China is the largest garment producer and exporter in the world but the production cost in China is increasing day by day beside recent year in China middle class are increasing very dramatically (Dr. Mahfuz Kabir, 2016) Which is why many producers and investors are shifting investment to others sectors and so many investors and producer are looking for a new destination. In this situation Bangladesh can take this opportunity to export their RMG in Chinese market.

Table: Export of BD RMG to Chinese market (2008-2016)

\begin{tabular}{|l|l|}
\hline Year & Export of BD RMG to China(mill\$) \\
\hline 2008 & 197.78 \\
\hline 2009 & 141.8 \\
\hline 2010 & 143.44 \\
\hline 2011 & 221.77 \\
\hline 2012 & 245.56 \\
\hline 2013 & 285.04 \\
\hline 2014 & 304.94 \\
\hline 2016 & 241.75 \\
\hline
\end{tabular}

Source: Export Promotion Bureau (EPB, 2017)

Above mentioned data and informations we can see very clearly that RMG export to China is increasing so steadily. In 2008 Bangladesh exported to China only \$197.78 million and 2016 its exported 391.59 which is enough satisfactory. Riding on a duty-free trade privilege, Bangladesh's garment export to China increased 14.77 percent year-on-year to $\$ 391.59$ million in fiscal 2016-17 (BBS, 2017), something exporters are seeing as a sign that new opportunities are awaiting. China, the global leader in apparel business, has turned into a major export destination for Bangladesh because of its huge population with a growing section of middle-income households.

Moreover, China is shifting production from basic to high-end garment products and has a shortage of skilled labor. Garment manufacturers are also giving more preference to Chinese markets for a shorter lead-time and better prices from retailers and brands. Exporters are upbeat about Chinese markets as this potential can be a very good substitute for continued apparel export growth at a time when shipments to other traditional destinations like the US, EU and Canada is falling. During the 2008-2009 global recession, global trade experienced a significant slump but Bangladesh's export got a boost for increased shipments to China. Moreover, China has its own retailers and brands which buy a lot of garment items from Bangladesh. Export of trousers, denim, non-denim and t-shirts, is high from Bangladesh to China. In this situation Bangladesh needs strong position for the Chinese markets. The growing Chinese middle class are the main customers of Bangladeshi apparel, exporters. Chinese manufacturers produce high-end garment products which middle class consumers can hardly afford. As a result, demand for Bangladeshi garment items is high. Since Chinese manufacturers have already shifted their focus to high-end products, the Chinese government started exploring an alternative market for middle class consumers. As a measure, the Chinese government in April 2011 allowed duty-free access to 4,721 Bangladeshi products, of which a majority are garment items. Since then, garment export to China from Bangladesh is on the rise. Recently, a study by Switzerland-based International Textile Manufacturers Federation (ITMF) said by the end of 2020, China would produce US $\$ 750$ billion worth garments from the current US $\$ 300$ billion, half for export and the remaining for domestic use (Daniel, 2017). Currently, about 80 percent of China's garment products are produced for local consumption. So Bangladesh should focus on this Asian economic giant for its future export growth.

\section{FDI in RMG Sector:-}

Bangladesh government has taken some major step to attract foreign investment in RMG industry. In order to attract foreign investment government has been offering some special incentives for investors which is why foreign direct 
investment is increasing very dramatically specially on readymade garment sector. Which is the main source of export earnings of Bangladesh. In 2016, the total amount of FDI in Bangladesh garment sector was around 489 million USD and it's increasing very rapidly in recent year (Bangladesh Bank, 2017). Last few years' garments and textiles production cost in China is getting higher, so the investors from all over the world choose Bangladesh as their new destination country. In the table we can see the total FDI in Bangladesh RMG sector is increasing year by year. To boost up this investment rate in this particular sector Bangladesh government is working to make some especial export processing zone across the country only for the garments industries. In this regard a comparative statistic is given below in a table.

Table: Total and RMG sector FDI (2008-2016)

\begin{tabular}{|l|l|l|}
\hline Year & Total FDI in Bangladesh(mill\$) & Total FDI in RMG sector(mill\$) \\
\hline 2008 & 666.3 & 230.35 \\
\hline 2009 & 1086.3 & 157.94 \\
\hline 2010 & 716.16 & 225.17 \\
\hline 2011 & 913.02 & 272.04 \\
\hline 2012 & 789.04 & 307.47 \\
\hline 2013 & 1194.88 & 421.63 \\
\hline 2014 & 1730.63 & 390.92 \\
\hline 2015 & 1480.34 & 447.78 \\
\hline 2016 & 1833.87 & 489.67 \\
\hline
\end{tabular}

Source: Foreign Investment \& External Debt (FIED) Division, Statistics Department,

Bangladesh Bank (2017)

\section{Chinese FDI in Bangladesh:-}

Since the establishment of diplomatic relation between China and Bangladesh China emerge as a largest trading partner of Bangladesh. Besides it's emerge as a reliable investment source of Bangladesh in these year. China is the third biggest FDI source country, China is investing huge amount of money in different part of the world, but Bangladesh did not able to get much attention to Chinese investors. In 2013 China invested to Bangladesh only 81.86 million USD and it's increased to 361.89 million in the year of 2016 (Dr. Samiul Parvez, 2015). It is a very dramatic change, and hope so in future there is a big possibility to increase this rate. As we know the production cost in China is going up, at that moment Chinese investors has been started to come Bangladesh. Along with the mainland China, Hong Kong and Taiwan are also investing to Bangladesh though investment amount of those two part of China is quite bigger than China mainland. In this regard a comparative statistic is given below in a table.

Table:- Chinese FDI inflow in Bangladesh. (2008-2016)

\begin{tabular}{|l|l|}
\hline Year & Chinese FDI in Bangladesh(mill\$) \\
\hline 2008 & 48.14 \\
\hline 2009 & 60.3 \\
\hline 2010 & 63.84 \\
\hline 2011 & 104.84 \\
\hline 2012 & 54.12 \\
\hline 2013 & 81.86 \\
\hline 2015 & 111.41 \\
\hline 2016 & 297.41 \\
\hline
\end{tabular}

Source: Foreign Investment \& External Debt (FIED) Division, Statistics Department, Bangladesh Bank (2017)

\section{Chinese FDI in RMG Sector:-}

As the most emerging sector of Bangladesh RMG industry having more foreign investment than others sector in this years. Especially in RMG sectors Bangladesh government is providing so many incentives for investors. Also Bangladesh government had allocated land in Chittagong's Anwara upozila for Chinese Economic and Industrial Zone. The government is setting up 22 special economic zones to facilitate such investment. Chinese investor can enjoy is that more than $90 \%$ per cent of their products, such as T-shirts, jeans, sweaters and casual trousers enjoy duty free access to the Chinese market, also they can enjoy GSP advantage in Europe and American market. 
(Mostak \& Sun, 2015).So Bangladesh RMG sector is attracting more FDI in recent year from China. In this regard a comparative statistic is given below in a table.

Table:- Chinese FDI inflow in RMG sector of Bangladesh. (2008-2016)

\begin{tabular}{|l|l|}
\hline Year & Chinese FDI in Bangladesh RMG Sector(mill\$) \\
\hline 2008 & 31 \\
\hline 2009 & 36 \\
\hline 2010 & 30.19 \\
\hline 2011 & 38.15 \\
\hline 2012 & 43 \\
\hline 2013 & 68.41 \\
\hline 2014 & 46.41 \\
\hline 2016 & 78 \\
\hline
\end{tabular}

Source: Foreign Investment \& External Debt (FIED) Division, Statistics Department, Bangladesh Bank (2017)

As we know the production cost in China is increasing very rapidly in recent year that's why so many investors are looking new destination for their investment though the investment rate from china is not that much satisfactory. In this context to increase Chinese FDI in Bangladesh garment sector Bangladesh government decided to make a new EPZ area including only Chinese investors in garment sector. So, it will open a big opportunity for Chinese investors in Bangladesh particularly in RMG industry.

\section{Opportunities of RMG Sector:-}

For last couple of decades Bangladesh readymade garments industry emerged as a major sector of Bangladesh economy. This sector is playing very important role in Bangladeshi economy. The most strength side of this sectors is cheapest labor force with good skill in the world in addition around 4 million workforces are working in this sector where most of them are women and from rural area. Which is now second largest garment producer and exporter in the world. Now in this sector there are a many kind of opportunities for foreign investors. As Bangladesh has a huge supply of young workers, with most of the four million garment workers in the country being young women, and they are very skilled for manufacturing garment. Beside this sector enjoying some specific advantage in EU and USA market (Shariful, 2017). On the other hand, we can see recently many Chinese firms are moving to Bangladesh to make their clothes, because of increasing labor cost. Not least because China is the global leader in clothing manufacturing and exports. But the shift is happening for very obvious reasons. Rosa Dada of Four Seasons Fashion Limited, a Chinese garments manufacturer says, factories in China are not competitive anymore because of increasing wages of laborers and a sharp hike in overall production costs. If I produce here, price is much more competitive, says Rosa Dada, Four Seasons Fashion Limited. But in Bangladesh the average monthly salary for garments workers is only around $\$ 70$ to $\$ 100$ (Forrest, 2016). According to industry figures, the average hourly wage for a Bangladeshi worker is just US $\$ 0.24$. This is well below the US $\$ 0.45$ payable in Cambodia, the US $\$ 0.53$ in Vietnam and only a fraction of the mainland's US\$1.26 (Yardley, Jim, 2012). So Lower labor costs will attract more investment from China. Another advantage they can enjoy more than $97 \%$ per cent of their products, such as T-shirts, jeans, sweaters and casual trouser s duty free access to the Chinese market. Also, now Bangladesh is a least developed country (LDC) and it is enjoying some specific advantages as a LDC country. Such as the cost of production and tax-free access to markets of European Union (EU) member countries, USA, Canada and also Chinese market. Even in 2010 China declared the more than 97\% Bangladeshi products will enjoy the duty-free market entry into China. S0 it's a big market for garment exporter of Bangladesh. The Chinese investors, who have moved out of RMG sector in their own country because of high labor costs and higher tariff slapped on their products by the developed countries, are particularly interested to invest on the Bangladesh RMG sector. In this situation Bangladesh should be a great place for investment, specifically on garments sector. According to investment return rate Bangladesh is in top 20, which is pretty much attractive. Because RMG industry of Bangladesh now contributes for over $82 \%$ of the country's total export earnings and this is covered $16 \%$ of the total GDP (Jonathan, 2017). In this situation Bangladeshi RMG industry could be very attractive destination for investors and buyers. 


\section{The Impact of OBOR in Bangladesh:-}

The One Belt One Road (OBOR) initiative of china is one of the biggest initiative taken by a single country ever in the planet. This (OBOR) initiative will be connected with more than 60 countries and $60 \%$ total population of the world and 40 percent of global GDP which is really amazing (Will, 2017). Undoubtedly it has deep and long term impact on global economy as well as Bangladesh. Bangladesh also will be benefited by this OBOR project as Bangladesh is one of the important trading partner of China. Since establishment of diplomatic relation between two countries China gradually emerged as largest import and source of investment destination of Bangladesh and its becoming stronger day by day. According to trade map data, in 2017 China's export to Bangladesh was to the tune of about 16 billion USD (The Daily Star, 2017). Indeed, over the past years China has gradually replaced India as Bangladesh's most important import-sourcing country. Bangladesh's export-oriented industries depend significantly on import of cotton fabrics, equipment, iron and steel from China; Bangladesh's domestic enterprises depend on Chinese machinery; a large part of consumption demand is met from imports of Chinese consumer goods. As is known, on the basis of purchasing in the world. Its imports amount to 1,682 billion in USD in 2016. Many developing economies are taking advantage of closer economic ties with China, particularly those in Asia and Africa. Thus, the critically important factor from the Bangladesh perspective is whether she will be able to benefit by deepening economic cooperation with the fast-growing Chinese economy, through greater exports and by drawing larger investment flows from China. Till now, against the aforesaid import of over 16 billion USD, Bangladesh's export to China had been only about 993 million USD in 2017 (Shang, 2017). This is only 0.05 per cent of China's annual import of 1,682 billion USD for that year. Attracting Chinese investment that targets the Chinese market (as also the global market) is key to reducing the bilateral trade deficit with China, by taking advantage of OBOR initiative. As a least developed country (LDC), Bangladesh is a beneficiary of the duty-free initiative of China under the WTO which offers duty-free market access to a large number of exports originating from the LDCs. An analysis of Bangladesh's export potentials in the Chinese market indicates that a power parity, China now ranks as the number one economy of products including lower-end apparels, leather and footwear items, jute products and pharmaceutical items have good export opportunities in China. If Bangladesh is able to diversify her export base and supply-side capacities, China with its growing middle class and increasing purchasing power could offer an excellent market opportunity for Bangladesh. As is known, a number of Agreements, MoUs and business deals, both Government to Government ( $\mathrm{G}$ to $\mathrm{G}$, worth about 24.5 billion USD for 28 projects) and Business to Business (B to B, worth about 13.6 billion USD for 13 deals), were signed between the two countries during the visit of the Chinese President in 2016.

Many of the proposed Chinese projects are geared to putting in place the necessary infrastructure in Bangladesh including those related to power generation, capacity building of ports and establishment of transport connectivity. Earlier, Bangladesh had shown keen interest in getting Chinese support for a number of projects including expansion and modernization of Mongla port facilities, extension of underground mining operation in Bara Pukuria, construction of coal-powered thermal plant, conversion of meter-gauge to broad-gauge track from Akhaura to Sylhet, BPDB's pre-payment metering project and construction of a marine drive expressway in the southern coastal

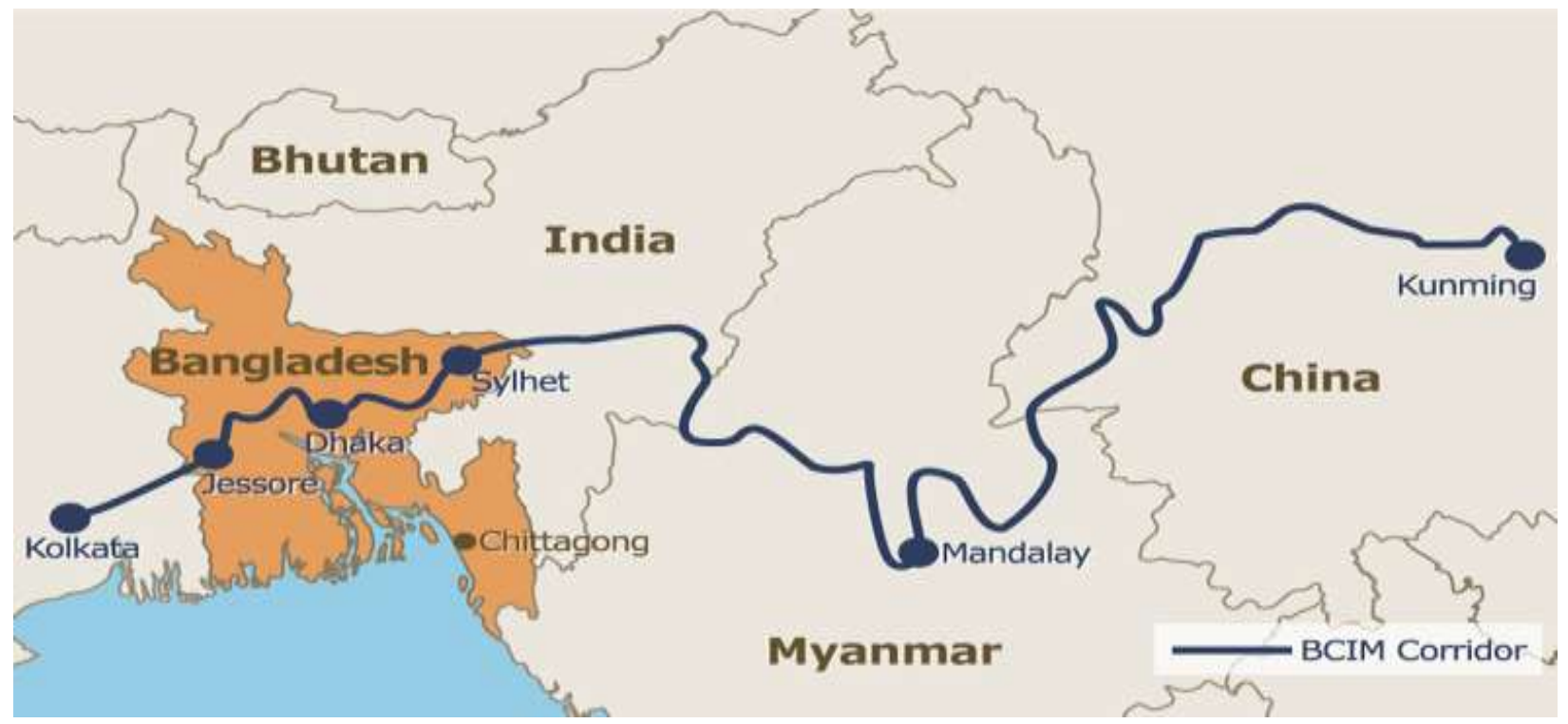


belt. Transfer of technology could be yet another opportunity from the viewpoint of deepening Bangladesh-China bilateral relationship. As is known, China has developed effective technologies for high productivity agriculture, exploitation of marine resources and deployment of satellite technology for better use and management of resources. China's support for ushering in a new technological frontier in agriculture, skills development and exploration and exploitation of resources in the Bay of Bengal zone could strengthen Bangladesh's efforts towards accelerated economic growth and enhanced welfare of her people. Support from the Asian Infrastructure Investment Bank (AIIB), established at the initiative of China could also be harnessed to mobilize additional funds towards the muchneeded infrastructure development in Bangladesh. China is now diversifying its investment into emerging markets and Bangladesh needs to take advantage of this economic opportunity. As part of the Bangkok Agreement, China provides Bangladesh duty free access to a list of Bangladeshi products. It is expected that bilateral trade between China and Bangladesh may exceed US $\$ 30$ billion by 2021 (Jonathan, 2017). As both Bangladesh and China believe in regional cooperation and have common interest in the corridor, this offers additional impetus. China has been increasingly developing its cooperation with South Asian nations. While Chinese investors have interests in Bangladesh's garment industry due to the availability of cheap labor, the Chittagong and Mongla ports are also of great interests for China to develop connectivity for its Southern gateway. Since China's OBOR initiative fits into Bangladesh's goals of connectivity and increased trade, Bangladesh now needs to make all efforts to ensure good governance and political stability so that it can achieve the aims and expectations of OBOR, which could have a great impact on the long term future of the economy of Bangladesh.

\section{The Impact of OBOR on RMG Industry:-}

Bangladesh is an emerging economic power in Asia and the garments industry has emerged as the backbone of its economy for last couple of decades which is the second largest RMG producer and exporter in the world market after China. RMG industry of Bangladesh now contributes for over $82 \%$ of the country's total export earnings and this covered $16 \%$ of the total GDP. (The Daily Star 2017). Very recently, Bangladesh Garments Manufacturer and Exporter Association (BGMEA) has fixed a goal to export $\$ 50$ billion by 2021 and finally become the largest RMG producer and exporter in the global market near future. As we know China is the Second largest economy after America and largest economy by (PPP) in this world, also it is the largest garments producer and exporter in the world market. At the same time Chinese government has taken One Belt One Road (OBOR) Initiative. This (OBOR) initiative will be connected with more than 60 countries and $60 \%$ total population of the world and 40 percent of global GDP. It will have a deep and long term positive impact in the world economy as well as Bangladeshi economy especially on RMG industry. It's could be a questions that why and how Bangladeshi Garments industry will be benefited from this (OBOR) initiative. As we all know that recently China has been working hard to create a new version of its economy that is powered by high-end, hi-tech industries that can compete with the biggest and best in the world. Which is why the production cost of garments in China is increasing day by day. So it's very difficult to produce their garment continuously. Which is why recently the producers and investors are looking for a new destinations for their investment. Let's have an example Rosa Dada is a garment manufacturer, and he has been running a garments factory in the Chinese port city of Ningbo for nearly two decades. She says "in my factory in China, the salary of workers has been increasing steadily over the last few years, it has reached around $\$ 400$ to $\$ 500$ (£250 - £315) a month per worker (Textile Today, 2017). If I continue to produce there, our business will disappear. "In Bangladesh the average monthly salary for garments workers is only around $\$ 70$ to $\$ 100$. If I produce here, price is much more competitive, she told during her recent visit to Bangladesh to look for opportunities here. Bangladesh is a least developed country (LDC) and it is enjoying some specific advantages as a LDC country (Will, 2017). Such as the cost of production and tax-free access to markets of European Union (EU) member countries, USA, Canada and also Chinese market.

The Chinese investors, who have moved out of RMG sector in their own country because of high labor costs and higher tariff slapped on their products by the developed countries, are particularly interested to invest on the Bangladesh RMG sector. An analysis of Bangladesh's export potentials in the Chinese market indicates that a number of products including lower-end apparels have a good export opportunities in China. If Bangladesh is able to diversify her RMG items and supply-side capacities, China with its growing middle class and increasing purchasing power could offer an excellent market opportunity for Bangladesh. Here, Chinese (as also Indian and other) investment targeting the Chinese market, taking advantage of the current duty-free access, could play an important role. Duty-free offer of India to Bangladesh also creates opportunities for Chinese investment in Bangladesh targeting the Indian market. These should create new opportunities for Chinese FDI in Bangladesh. Chinese manufacturers say if they source clothes from Bangladesh, prices can come down by $10 \%$ to $15 \%$ depending on the category Forrest (Cookson, 2016). So they can choose Bangladesh for their investment. As because there is a chip 
labor forces than china. Regarding Chinese investment, particularly in Bangladesh's garment sector, prime minister of Bangladesh, said her government had allocated land in Chittagong's Anwara upozila for Chinese Economic and Industrial Zone. The government is setting up 22 special economic zones to facilitate such investment, said Ihsanul Karim PM's Press Secretary of Bangladesh. Bangladesh and China have enormous potentials in joint venture industries. So Chinese investor can invest easily, garment sector in Bangladesh. Because there is a strong possibility to get their expected profit. For example, A few years ago only 5\% of my factory output was for the Chinese market. Now it has gone up to $20 \%$, says a garment manufacturer. He also expects that number to increase further in the coming years.

The RMG sector is expected to grow despite the global financial crisis of 2009. As China is finding it challenging to make garment and textile items at cheap price, due to rising labor costs, many foreign investors, are coming to Bangladesh to take advantage of the low labor cost. Local accessories are being made including zippers, buttons, labels, hooks, hangers, elastic bands, thread, backboards, butterfly pins, clips, collar stays, collarbones and cartons. So it's a great opportunity for Chinese investor to investment in garment sector in Bangladesh. In order to accelerate economic growth, Bangladesh opened her economy in the late 1980s to reap the benefits of FDI. In 1989 the government set up Board of Investment (BOI). The primary objective of which is aimed at attracting and facilitating investment from abroad. Foreign investors have set up world standard garment units in the export processing zones (EPZs) in which laborers are working in sound environment and getting good salaries. The Bangladesh government has developed EPZs in different parts of the country to woo foreign investments in the 80s and 90s. The safety measures in the factories in the EPZs are international standard. In this regard Chinese investment will bring new technology, new management system from China to Bangladesh. On the other hand in Bangladesh it will create employment, increase infrastructure, increase GDP growth rate, increase the volume of export etc. So it will be good for both Bangladesh and Chinese RMG industry. Both countries will be able to enjoy absolute advantage for international trade and it will create a win- win situation. In perspective (OBOR) Initiative will bring more opportunities for this industry. After analysis the above mentioned data and informations it is very evident that China has emerged as a very important trade partner of Bangladesh and China has the biggest economic market especially RMG market in the world. Where Bangladesh is the second largest garments producer and exporter in the world after China, so it could be a great opportunity for the Chines investors and buyers who have been looking for new destinations for their investment. In this regard China's One Belt One Road (OBOR) Initiative Could be a windows of opportunities for Bangladesh Garments industry which will be very important gateway for Bangladesh to become number one garments producer and exporter in this world market. Finally it is very evident that there is a positive impact of One Belt One Road initiative (OBOR) on Bangladeshi garment industry.

\section{SWOT Analysis of RMG Industry:-}

Bangladeshi Readymade Garment (RMG) has emerged as an important destination for buyers and investors for last couple of decades (Akhi, 2017). Now it is the second largest RMG producer and exporter in the world after china. Although it has some opportunities and also some problems. After analyzing the data and Bangladesh RMG markets author has finalized the SWOT analysis of the RMG sector in Bangladesh. The SWOT analysis of RMG of Bangladesh is as follows:

\section{Strengths:-}

One of the strengths behind the success of RMG of Bangladesh is the availability of low cost labor force compared to other countries in the region.

\section{Strengths in Brief:-}

1. Comparatively low labor cost.

2. Energy at a reasonably lower price.

3. Wide ranges port facilities.

4. FDI is legally permitted by the Government of Bangladesh.

5. Improved Generalized System of Preferences (GSP) advantages.

6. All foreign investments in Bangladesh are secured by Foreign Private Investment Act, 1980.

7. Excellent Tele-communications network.

8. Weakness of currency against dollar/euro which persists to help exporters.

9. Low Bank interest, only $7 \%$ for financing exports.

10. A very competitive with a highly skilled labor force.

11. Effective monitoring and controlling system for better performance. 
12. Especial economic zone and incentives for investors.

\section{Weaknesses:-}

RMG industry of Bangladesh also has some weakness like political instability labor unrest child labor poor infrastructure nonstop power and gas and. Besides this, there are numerous demands for "under-the-table" payments that are reportedly required at every step of export processing, from opening of letters of credit to the clearance of goods from Customs.

\section{Weaknesses in brief:-}

1. Long lead-time of Export or Import

2. Lack of marketing tactics.

3. The country faces deficiency in creativity.

4. Foreign suppliers are often supply low quality materials, which result is low quality products.

5. Manufacturing methods are few.

6. Lack of proper training for industrial workers, supervisors and managers.

7. Custom clearance is lengthy process in Bangladesh.

8. Poor infrastructure and security.

9. Lack of none stop electricity.

\section{Opportunities:-}

As a least developed country Bangladesh enjoying some specific advantages such as duty free accessibility and GSP facilities in Europeans and America as well as China.

\section{Opportunities in brief:-}

1. EU is willing to move from china to Bangladesh to establish big enterprises.

2. Bangladesh is included in the Least Developed Countries with which US is committed to enhance export trade.

3. Japan is very interested in the purchase of handloom textiles, home furniture and garments from Bangladesh. Thus, RMG sector can be expanded with continued progress in quality.

4. The port of Chittagong in Bangladesh will be handed over to the foreign operator which will reduce lead-time as well as total cost will be decreased.

5. As Bangladesh is one of the most important member of (OBOR) initiative.

6. RMG of Bangladesh is very well known in the world market.

\section{Threats:-}

There are some Specific threat is also before Bangladesh. There are some others countries also doing very well in this sectors such as Vietnam, Turkey, and India. As a largest RMG producer China is another threat for Bangladesh.

\section{Threats in brief:-}

1. China is likely to be the biggest threat for Bangladesh RMG sector because of the capital-intensive modern technology and locally available raw materials like fabrics, RMG accessories etc.

2. As comparing to Bangladesh, China has better energy supply, transportation and communication systems.

3. Some countries in Africa have had zero-tariff facility under AOA act (Agreement on Agriculture) which helps them to compete with Bangladesh RMG sector.

4. Recent recession in America and European countries.

5. International terrorism.

\section{The Main Challenges in this Sector:-}

Despite RMG industry is the most important and fastest growing sector of Bangladesh's economy it has so many problems and challenges in this sector. The most important problems are political instability, labor unrest lacking of gas, electricity, infrastructure and some bad images (Ahmed et al 2013). In addition, this sector really needs to ensure smooth delivery of products and long-term energy policy. Bangladesh's competitive advantage is its young workforce and comparatively low wages but production costs have gone up recently due to compliance issues. The BGMEA official said better policy support, along with better training and education for the workforce, are essential for the growth of export industry. Workers' productivity and efficiency - key tools in reducing production cost, are also a big challenge for the RMG sector in Bangladesh. The majority of the factory owners have upgraded the production process by introducing the latest technology. But, due to the inefficiency at mid-level management, 
workers fail to reach targeted productivity. Due to longer lead times, buyers choose others exporting countries to source products from Bangladesh. Here we tried to find out some problems and difficulties for the foreign direct investment and Chinese investment in Bangladesh.

First, political instability and uncertainty is the main problems in Bangladesh. Since the independence Bangladesh has been facing so many political incidence. The political clash between government and other political parties are very often issue. The opposite political parties offer strike and some other activities against government, they burned public and private transportation, office, school, colleges all are closed off. In this situation not only, Chinese investors but also all investors around the world won't be interested to invest in Bangladesh.

Second, lacking of good images are another problems in Bangladesh. When someone want to know about one country, firstly they search it in internet and read about that country. Most of search engine with the keyword Bangladesh contains mostly bad news and images beside some tragic accident in Bangladesh garments sector in the last few years also created negative impact on this sector. In November 2012 Tazrin Fashion factory burn out at Asulia which is near Dhaka, by this accident 120 people were died. In April 2013 there was another big accident had happened in Bangladesh garments sector. There was a garment factory named Rana Plaza collapsed down at Savar and more than 1129 garments workers were dead (Butler, 2013). Which is why Bangladesh is always being present negatively in the world media'

Third, inconvenient and old transportation system and infrastructure in Bangladesh is also another major problems to attract foreign investment. Investors always looking for good infrastructure. But Bangladesh can't guarantee the proper gas, electricity and others service to the investors. The transportation system in Bangladesh also not good, narrow and broken road is the cause of property damaged. Bangladesh also has a huge traffic jam, due to the lacking of proper urban planning Bangladesh can't solve this issue for the long time.

Fourth, corruption is one of the most important problems in Bangladesh. So it's not good for Bangladesh, when one investor want to invest in one country definitely they look over the transparency report. So this would be discouraging factors of investment. The extra cost of doing business and bureaucratic delay is high and its increase the production cost and time.

Fifth, Bangladesh has a huge human resource and most of them are young and operative. But they are not enough educated, well trained, skilled as well as less productive. The managing skill of Bangladeshi managers are also lower than other Asian countries. It is reducing both of the production efficiency effectiveness.

Sixth, lack of good governance and policy. Investment is a long time process, and the investment result also long time process. But in Bangladesh government and political parties changes the policy during the short period of time. When new government come to the power they change the policy as their ways. Which is affecting negatively for the investors to invest in Bangladesh. In this situation not only, Chinese investors but also all investors around the world don't like Bangladesh as their investment destination.

Seventh, the work environment of garment factory is not good enough as well as not secure and healthy. Last some years several accident happened in this sector which was really pathetic. Except above mentioned problems Bangladesh has more some problems in this sector.

\section{Recommendations for Bangladesh:-}

Readymade Garments industry of Bangladesh has a great prospect to become number one RMG exporter by taking advantage of One Belt One Road (OBOR) initiative. But due to some specific reason such as political turmoil, insufficient of gas, electricity, poor infrastructure, lack of security, corruption and some negative images the foreign investors are discouraged to invest Bangladesh. Which is why some other rising developing economic countries are taking this chance and the investors are investing to others places except Bangladesh. Despite Bangladesh has a great opportunity in garment and textiles sector. In this situation Bangladesh should be more careful to attract those investors who are leaving China. What this sector really needs is better infrastructure to ensure smooth delivery of products, a long-term energy policy is essential for supplying gas and electricity to the factories at an affordable price. Bangladesh's competitive advantage is its young workforce and comparatively low wages so Bangladesh has to proper use of that human resource beside better policy support, along with better training and education for the workforce. If, Bangladesh wants to be a hotspot for the RMG industry, factory owners will have to treat workers 
with dignity and have to insure their proper right. Besides completion of accord and alliance inspections will help Bangladesh boost exports in future. In order to solved inefficiency of the Chittagong port Bangladesh government must take measures to modernize existing ports, and also set up a deep-sea port to improve growth in the export sector and overcome timing problems. If Bangladesh can solve the identified common problems to invest in this sector Bangladesh could be benefited from the (OBOR) initiative by many ways and it would be the number one RMG exporter in the world in future. After this discussion, there are some suggestions to Bangladesh to impress and attract more investors and buyers in this sector.

First, it's true that the main problems in Bangladesh is political unrest. It's not only obstacle for RMG industry but also for all over the economy of Bangladesh as well as for foreign investors. In this regard Bangladesh government should be taken some proper and acceptable steps to solve such kind of problems.

Second, As Bangladesh is one of the corrupted country in the world, government must have to take some proper steps to eradicate this major problems. In order to eradicate the corruption, every sectors in Bangladesh should be modern and digitalized. So that every things could be easy and investors would be encouraged.

Third, inconvenient and old transportation system and infrastructure in Bangladesh is also another major problems to attract foreign investment. So Bangladesh need to more concentrate to improve the overall infrastructure system which is very important factor for investment. Investors always looking for good infrastructure so Bangladesh have to guarantee the proper gas, electricity and others service to the investors. So that investors could be more interested to invest in Bangladesh.

Fourth, Bangladesh has a huge human resource and most of them are young and operative. But they are not enough educated, well trained, skilled as well as less productive. In this regard Bangladesh government should take some effective step to make them more educated, skilled and more productive.

Fifth, although Bangladesh is a democratic country but the system is not that much strong and sustainable. The government policy is being changed whenever new party comes to power. It is considered that incentive policies of governments are positively related with FDI attraction. So, government should to make a long-time rules and regulations what can make sure the investors and their investment security.

Sixth, the work environment of garment factory is not good enough as well as not secure and healthy. Last some years several accident happened in this sector which was really pathetic. In order to stop the repetition of this unexpected accident Bangladesh should pay more attention to this sectors. Besides the owners have to make sure the healthy work environment and secure conditions in this sectors. Having child daycare garden could be another requirement for the workers.

Finally Bangladesh government can arrange some seminar and exhibition to promote the RMG sector in the world stage. If Bangladesh can follow the above mentioned recommendation then Bangladesh RMG industry could be benefited from One Belt One Road initiative and have prospect to become number one RMG exporter in the world.

\section{Conclusion:-}

Readymade garments industry (RMG) has emerged as a backbone of Bangladeshi economy for last couple of decades. This sector has been emerging very rapidly than others sectors of Bangladesh. Recently Bangladesh government, led by Prime Minister Sheikh Hasina, is firmly committed to materializing two important visions: a) becoming a middle-income country by 2021 and b) becoming a Developed Country by 2041. Beside Bangladesh Garment Manufacturer and Exporter Association (BGMEA) has fixed up a goal that export $\$ 50$ billion by 2021 and become largest garment producer and exporter in the world which currently second largest. Bangladesh Government is fully aware that for achieving that goal, greater regional cooperation and enhanced connectivity are important. In order to achieve the goal fixed up by government and BGMEA, One Belt One Road initiative (OBOR) could play major role. As we know China is the second largest economy in the world after America and largest economy as PPP. As Bangladesh is one of the important country of this initiative as economically and geopolitically. In order to make more strong this economic and geopolitics relations between two countries recently Chinese precedent $\mathrm{Xi}$ Jinping visited Bangladesh in October 2016. This two countries have signed several agreements for investment and mutual cooperation. Which will help for attracting more Chinese investors in Bangladesh especially on Garment 
sectors. Through this OBOR initiative Bangladesh could be benefited in various ways because this project will be connected more than 60 countries in Asia Europe and Africa which is very important RMG market For Bangladesh. Beside China would be the very important destination for Bangladeshi RMG export which is the most populated country and big market in the world. Bangladesh as a least developed country enjoying some specific advantage. Such as the cost of production and tax free access to markets of European Union EU member countries USA Canada Australia. The most important news is recently Chinese government has declared more than 97\% Bangladeshi products include RMG will enjoy duty free accessibility in Chinese market. Which is really a big windows of opportunities for Bangladeshi RMG export as well as Chines investors and buyers who is looking for a new destinations for their investment due to increasing the production cost in China recently. In order to take this opportunities Bangladesh government has offering some especial incentives for attracting foreign investors in this sectors. Especially Bangladesh government has already made some Especial economic Zone for investment specific on garment industry. Recently Bangladesh government has allocated one especial economic Zone at Anowara Upozela in Chittagong district which is only for Chinese investors. Chinese investment will bring new technology, new management system from China to Bangladesh. On the other hand in Bangladesh it will create employment, increase infrastructure, increase GDP growth rate, increase the volume of export etc. So it will be good for both Bangladesh and Chinese economy. Both countries will be able to enjoy absolute advantage for international trade and it will create a win-win situation. So Bangladesh government also should to take some initiative to improve infrastructures, political stability, monetary policy, labor skill and other related steps. Chinese investors can take this big opportunities to set up their factories and fulfill the demand of China, not only China but also they can export the products from Bangladesh to all over the world with very easy market access. And by this process both countries could be benefited. Finally, we can say that One Belt One Road (OBOR) initiative could be a massive window of opportunities for Bangladesh especially RMG industry.

\section{References:-}

1. Abdin MJ (2014) Cluster Development for Inclusive and Sustainable Economic Growth, Professionals Center for Business Research.

2. A.H.M Moazzem Hossain (18 May 2017) China to become biggest investor in Bangladesh with Chevron acquisition.

3. Alam MS (2012) Foreign Direct Investment in Bangladesh: A Critical Analysis, South East Asian Journal of Contemporary Business, Economics and Law.

4. Anna Bruce-Lockhart Editor, World Economic Forum (20 Jan 2017) Is China the new world power? The view from Davos.

5. Abdin, M. J. (2008). Overall problems and prospects of Bangladeshi ready-made garment industry. SSRN Electronic Journal, http://www. Research gate.

6. Ahmed, S., Raihan, M. Z., \& Islam, N. (2013). Labor Unrest in the Ready-Made Garment Industry of Bangladesh. International Journal of Business and Management, 8(15), 68.

7. Atm Adnan July 2016 Ready-Made Garments Sector of Bangladesh: Its Contribution and Challenges towards Development.

8. Akhi Akter 15 feb 2017 textile today An over view of Bangladesh readymade garments 2016.

9. By Tian Jinchen (Article July 2016) 'One Belt and One Road': Connecting China and the world.

10. Bangladesh Economy is a Star in the World Economy says UN Expert" (PDF). United Nations. 2011. Retrieved July 6, 2013.

11. Bangladesh-China economic military and diplomatic relations (October 20, 2016)Berg, A., Hedrick, S., Kempf, S. \& Tochtermann, T., (2011) Bangladesh's Ready-made Garments landscape: The challenge of growth. McKinsey \& Company, Inc. Begum AA, Abdin MJ (2015) Employment Generation and Poverty Alleviation through SME Cluster Development in Bangladesh, Turkish Economic Review 2: 26-31.Bangladesh Govt. proposes new law for RMG sector". Dhaka: Bangla Apparel. 1 September

15. Bettina Wassener, Global Business, April 23, 2012. In an Unlikely Corner of Asia, Strong Promise of Growth.

16. Bangladesh Government is setting up 22 special economic zones to facilitate such investment, said Ihsanul Karim PM's Press Secretary OF Bangladesh. [The Daily Star BD]

17. Butler, S. (2013, June 22). Primark backs safety drive in wake of Bangladesh factory disaster.The Guardian.

18. Businesses Keith Bradsher and Paul Mozur march 7, 2017 China's Plan to Build Its Own High-Tech Industries Worries Western

19. Cheang Ming News Assistant Justina Crabtree | Cheang Ming (Monday, 22 May 2017 | 5:16 AM ETCNBC.com) Why soft power could be the real value of China's massive Belt and Road project. 
20. Chowdhury, M.A.M., Ali, M.M., and Rahman, R. (2005). WTO, Post MFA Era and the Bangladesh RMG Sector: An Assessment of the performance and challenges. Journal of the Institute of Bankers Bangladesh, 52 (2):87-120.

21. Chowdhury, M., Ahmed, R., Yasmin, M., (2014) Prospects and Problems of RMG Industry: A study on Bangladesh. Research Journal of Finance and Accounting, Vol.5, No.7, 108-109.

22. Clark, C., and Kanter, S. (2011). Violence in the Readymade Garments (RMG) Industry in Bangladesh. International Journal of Business and Management, Vol. 7, No. 3, 1833-8119.

23. Divyansh Awasthi-28 Feb 2017. Bangladesh Will Be Amongst Top 3 Fastest Growing Economies Globally Through 2050

24. Dr Samiul Parvez Published on Aug 06, 2015 Published in: Data \& Analytics China-Bangladesh" Trade Relations.

25. Daniel Workman November 24, 2017 (China's Top Trading Partners)

26. Dr Mahfuz Kabir, October 10, 2016. Expanding the Bangladesh-China trade frontier

27. Express Web Desk | New Delhi | Updated: May 14, 2017 6:10 pm) what is China's One Belt One Road (OBOR) project?

28. Ferdous Ahamed, PHD. Improving Social compliance in Bangladesh's Readymade Garment Industry.

29. Forrest Cookson, 29 November 2016. New markets for Bangladesh garments.

30. Foreign Direct Investment in Bangladesh 1971-2010 (2010) the Board of Investment, Government of Bangladesh.

31. Foreign Direct Investment (FDI) in Bangladesh, Survey Report (2014) Statistics Department, Bangladesh Bank.

32. Fauzia Ahmed. "The Rise of the Bangladesh Garment Industry: Globalization, Women Workers, and Voice."

33. Hasan, J., (2013). The Competitiveness of Ready Made Garments Industry of Bangladesh in Post MFA Era: How Does the Industry Behave to Face the Competitive Challenge? British Journal of Economics, Management \& Trade, 3(3): 296-306.

34. Huffington Post, September 4, 2014 2014. Connectivity of the Silk Route countries.

35. Isaac Stone Fish Jun 2, 2017. Is China Becoming the World's Most Likeable Superpower?

36. International Monetary Fund, www.imf.org. Data Base, world economic outlook, GDP, 2014.

37. Jonathan Garber Apr. 7, 2017 Business Insider. There's a new 'Asian Tiger'

38. Mostak Ahamed and Sun Ying, 2015. Chinese investment in Bangladesh garment sector.

39. Ma Ming Qiang, Chinese ambassador to Bangladesh, The Daily Prothom Alo, October1, 2017, China will be number one investor in Bangladesh.

40. Nusrat Zahan, February 28, 2017. Bangladesh joins China's 'One Belt, One Road' initiative: meeting challenges, building the future, Shanghai Daily condensed the article.

41. Nake M. Kamrany and Frank Jiang, The World Post. China's Rise to Global Economic Superpower.

42. Reuters, May 15, 2017. Xi Jinping Says the Rejection of Protectionism Is Part of What 'One Belt, One Road' (Xinhua net 2017-03-30) Sino-Bangladesh bilateral trade set to boom as China's Belt and Road initiative takes shape.

43. Renmin University of China (RUC), Beijing, China, June 27 - 28, 12 countries Think Tank Forum, Proceedings of Conference. The Silk Road Economic Belt Construction and Future.

44. Shariful Islam Assistant Professor of International Relations, University of Rajshahi.BD. China's 'One Belt, One Road' Initiative How Bangladesh can be benefitted.

45. Shang jinwei, The Daily Prothom Alo, October15, 2017. The economical possibility of one belt one road.

46. South China Morning Post (Bangladesh plugged into China's belt and road scheme, HSBC banker says.

47. The Daily Star, July 12, 2017. Bangladesh to benefit from China's belt, road initiative: MCCI

48. The Daily Prothom Alo, Jun 12, 2017. Bangladesh must be ready for the 'One Belt One Road' initiative

49. The Daily Star, May 19, 2017. China's 'One Belt, One Road' Initiative How Bangladesh can be benefitted

50. Textile Today 8th Feb 2017 Investment is bouncing back in Bangladesh textile and clothing sector.

51. World Investment Report (2014) United Nations Conference on Trade and Development (UNCTAD).

52. Will Martin. 2017-08-07. most powerful economies in the world by 2050.

53. Yardley, Jim, The New York Times, 23 August 2012. "Made in Bangladesh: Export Powerhouse Feels Pangs of Labor Strife". 